Reprod. Nutr. Dévelop., 1984, 24 (3), 307-314.

\title{
Effects of microflora on the dimensions of enterocyte microvilli in the rat
}

\author{
J.-C. MESLIN, E. SACQUET $\left({ }^{*}\right)$
}

with the technical assistance of S. DELPAL

Station de Recherches de Nutrition, I.N.R.A., 78350 Jouy-en-Josas, France.

(*) Laboratoire des Animaux sans Germes, CNRS, INRA, 78350 Jouy-en-Josas, France.

Summary. The length and diameter of enterocyte microvilli at mid-villus position were measured on electron-micrographs. The duodenum, jejunum and ileum of axenic (germfree) and holoxenic (conventional) inbred rats fed the same diet have been studied. The microvilli were significantly shorter in all these intestinal regions when the microflora was present. The decrease in microvillus length (due to the presence of microflora), expressed as a percentage of the length in axenic rat, was $5 \%$ in the duodenum, $9 \%$ in the jejunum and $18 \%$ in the ileum. This was not true of microvillus diameter where only the values found for the ileum of axenic rat were significantly lower, the others not differing among themselves. In conclusion, the presence of a total microflora led to a decrease in the length of enterocyte microvilli. These results have been discussed in relation with studies on renewal and enzyme activity in the intestinal epithelium.

\section{Introduction.}

The microvilli represent a differentiation of the apical surface of the enterocyte ; this surface, which has an important function because it is the site of the absorptive cells of the intestine, is the first to come in contact with the diet, digestive secretions and microflora. Some enzyme activities involved in the absorptive process are also found in this brush border.

The presence of microvilli increases considerably the absorptive surface of the enterocyte apex (Anderson and Taylor, 1973 ; Stendling and Helander, 1981). The dimensions of the microvilli are affected by the migration of the enterocyte from the crypt to the apex of the villus (Toner, Carr and Wyburn, 1971), by fasting and refeeding (Misch, Giebel and Faust, 1980 ; Leeson and Leeson, 1981) and by the presence of microflora. Kenworthy and Allen (1966) found that the brush border of enterocytes in the jejunum of piglets monocontaminated with Staphylococcus albus was three times longer than that of piglets having a normal 
microflora. Gustafsson and Maunsbach (1971) reported that the microvilli of enterocytes in the cecum of axenic (germfree) rats were $25 \%$ longer than in holoxenic (conventional) rats. The presence of microflora also affects enzyme activities; alkaline phosphatase activity is more intense in the cecum of axenic than holoxenic mouse (Jervis and Biggers, 1964). The activities of alkaline phosphatase and of $\mathrm{Ca}^{++}$and $\mathrm{Mg}^{++}$ATPases which depend on the brush border, was well as the quantity of protein extracted from the border, are higher in axenic than in holoxenic rats (Reddy, 1971, 1972). Since the microflora alters some of the enzyme activities of the enterocyte (Yolton and Savage, 1976 ; Kawai and Morotomi, 1978 ; Whitt and Savage, 1980, 1981), there may be a relationship between the dimensions of the microvilli and the intensity of these enzyme activities. As the dimensions of the microvilli have not been determined systematically in previous studies, the present experiment was designed to ascertain if the presence or absence of microflora affected the development of enterocyte microvilli throughout the small intestine.

\section{Material and methods.}

We used 4 axenic and 4 holoxenic 4-month old inbred rats of the Fisher strain. One month before the experiment began, they received ad libitum a semisynthetic diet containing $200 \mathrm{~g}$ of casein, $580 \mathrm{~g}$ of cornstarch, $90 \mathrm{~g}$ of corn oil, $50 \mathrm{~g}$ of cellulose, $45 \mathrm{~g}$ of a mineral-vitamin mixture. This diet was sterilized by autoclaving. The animals were not fasted before the experiment.

The following samples were taken : duodenum $15 \mathrm{~cm}$ from the pylorus and before Treiz' ligament), jejunum (middle of the small intestine), ileum $(5 \mathrm{~cm}$ before the cecum). Ligated segments about $1-\mathrm{cm}$ long were prefixed by injection into the gut lumen of $2.5 \%$ glutaraldehyde in a $0.1 \mathrm{M}$ sodium cacodylate buffer, $335 \mathrm{mOsm}, \mathrm{pH} 7.6$; they were then cut again into very small pieces in the same fixative. These pieces were washed in $0.15 \mathrm{M}$ sodium cacodylate buffer, postfixed in $2 \%$ osmium tetroxide for one night, dehydrated and embedded in Epon with flat moulds of silicone rubber.

Semi-thin sections of the specimen blocks gave an overall view of the mucosa ; these blocks were retrimmed with an LKB pyramitome equipped with a target marker to obtain a mesa by trimming away all the crypts, the enterocytes situated at the base and the top of the villus ; only enterocytes located at midvillus position were examined. The microvilli were measured on 120 electronmicrographs $(\times 32000)$. To obtain the mean length of these microvilli, we measured them from their bottom to their apex (160 measurements per intestinal division in each group); microvillus mean diameter was estimated by the mean space occupied by 15 microvilli.

The results were compared between divisions and groups by analysis of variance and by the multiple-range test of Newman-Keuls (Newman, 1939 . Keuls, 1952). 


\section{Results.}

Figure 1 shows the measured lengths of the microvilli in the duodenum, jejunum and ileum in our axenic and holoxenic rats.

The microvilli were significantly shorter when microflora was present. In holoxenic rat, the length of the microvilli varied from the duodenum to the ileum : in axenic rat, the lowest value was found in the duodenum, while those in the jejunum and ileum were about the same (fig. 1). The decrease in microvillus length due to the presence of microflora, expressed as a percentage of the length in axenic rats, was $5 \%$ in the duodenum, $9 \%$ in the jejunum and $18 \%$ in the ileum.

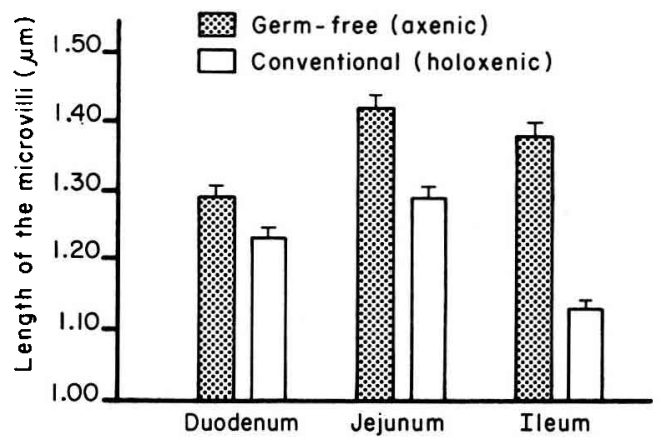

FIG. 1. - Length of the microvilli $(\mu \mathrm{m})$ in the duodenum, jejunum and ileum of germfree (axenic) and conventional (holoxenic) rats.

Figure 2 shows the mean diameter of microvilli in the duodenum, jejunum and ileum of axenic and holoxenic rats. The Newman-Keuls multiple-range test showed no wide difference between the two groups of rats; only the values in the ileum of the axenic rats were significantly lower, but this difference was very slight compared to that observed for microvillus length. There was no difference among the other values (fig. 2).

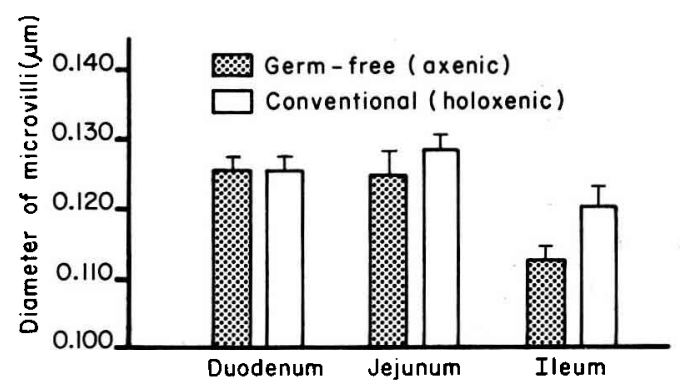

FIG. 2. - Diameter of the microvilli $(\mu \mathrm{m})$ in the duodenum, jejunum and ileum of germfree (axenic) and conventional (holoxenic) rats. 
The aspect of enterocyte microvilli in the ileum of axenic and holoxenic rats is shown in figure 3.

\section{Discussion.}

Variations in the size of the brush border, resulting from either the presence or absence of microflora or from differences in the state of differentiation and of enterocyte renewal (Leblond and Stevens, 1948), may thus partly explain differences in enzyme activities in the microvillus area.

1) Effect of the presence or absence of microflora on microvillus size. - The most important effect the presence of microflora had on enterocyte microvilli was to reduce their length ; microvillus diameter was very little changed. This effect was most apparent in the ileum, that part of the intestine where the microflora is most abundant. The decrease in microvillus length we observed in the ileum of rats $(18 \%)$, due to the presence of microflora, is in agreement with the value of $25 \%$ reported by Gustafsson and Maunsbach (1971) in the cecum of axenic and holoxenic rats. Our study proves that this process already commences in the duodenum. The differences in microvillus length between axenic and holoxenic rats, notable in the terminal part of the small intestine and even more so in the cecum, may be related with the amount of bacteria present since there is more in the hindgut.

The reduction in microvillus length in the presence of microflora seems to be a common feature in rodents ; Abrams, Bauer and Sprinz (1963), in a study on the influence of normal flora on mucosal morphology and cellular renewal in the ileum, observed that columnar absorptive cells appear to have a wider brush border in axenic than in holoxenic mice.

Kenworthy and Allen (1966) reported that the jejunal brush border was three times longer in piglets monocontaminated with Staphylococcus albus than in hoxolenic piglets. In this division of the small intestine, this higher difference (compared to our results in rats) may be due to the strain of bacteria and also to the fact that the mucosa of the small intestine does not react in the same manner in pig as in rat. Moon (1971) reported a shortening of the villi in piglet from birth to 21 days ; this is not observed in weanling, young or adult rats (Altmann and Enesco, 1967).

It has been said that microvillus length in rat varies according to the position of the enterocytes on the villi, the microvilli on villus apex cells being taller and thinner than those at the base (Palay and Karlin, 1959 ; Toner, Carr and Wyburn, 1971). We carried out observations on enterocytes situated at mid-villus position (1) to avoid cells near the shedding zone of the villus apex which might have shown alterations of the brush border and (2) because it has not been definitely shown that microvillus length increases along the villus side up to the apex of the villi in all animal species. Phillips, France and Walker-Smith (1979) found the longest microvilli within the mid-villus region in children.

2) Development of brush border, mucosal surface and epithelial renewal. As compared to the length of microvilli in holoxenic rats, the increased length of 


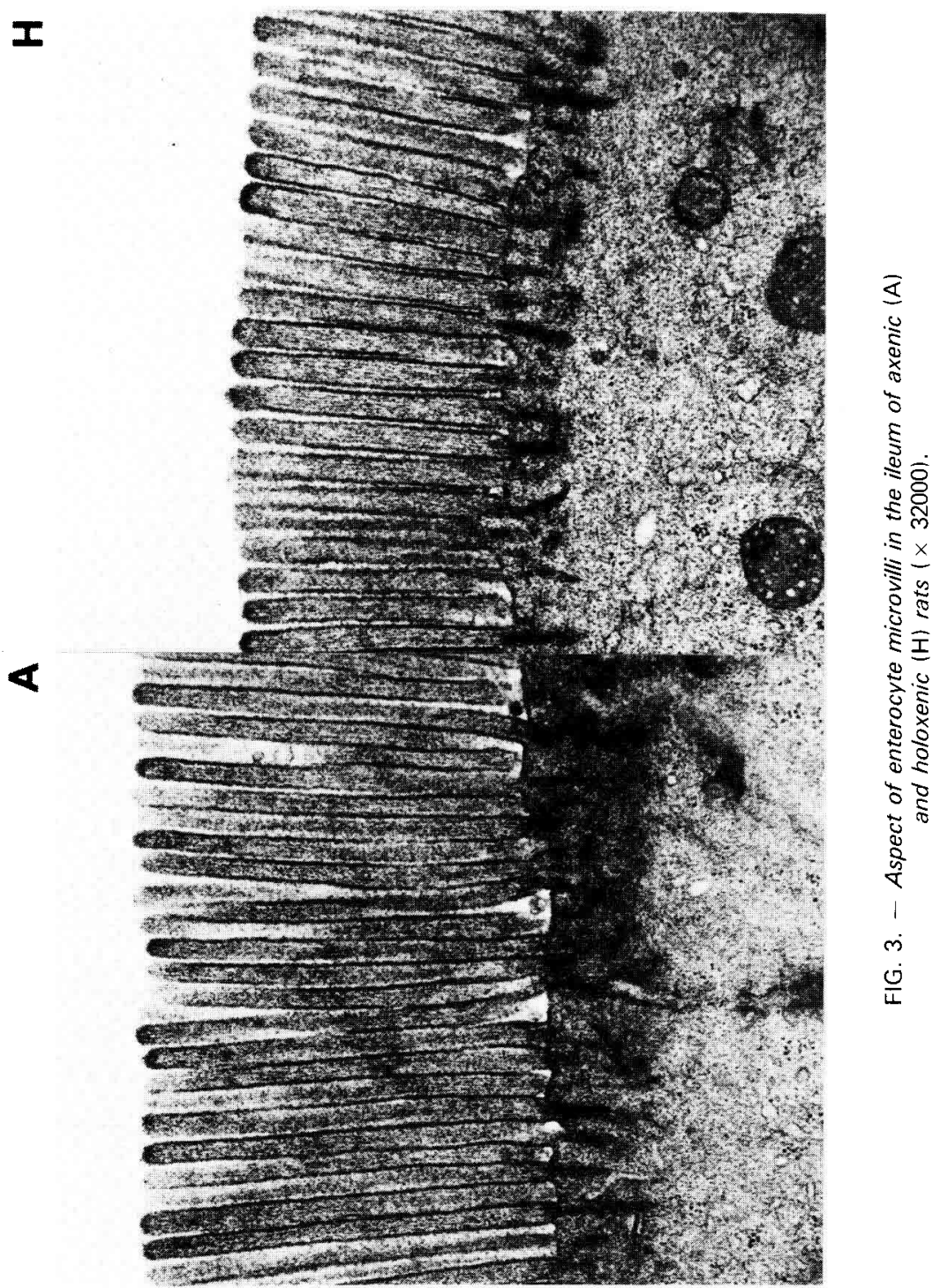


the microvilli in axenic rats tends to mitigate the decrease in the mucosal surface of their jejunum and ileum (Meslin, Sacquet and Guenet, 1973).

Microvilus length increases when the enterocyte migrates from the crypt to the apex of the villus (Toner, Carr and Wyburn, 1971), and it may be that the longer microvilli in axenic rats are related with a slower renewal of the intestinal epithelium. This does not appear to be the case in the duodenum because slower renewal there is due to the greater number of cells to be replaced and not to the portion of labelled cells, which is the same as in holoxenic rats (Meslin, Sacquet and Raibaud, 1974). In the above study, we showed that the situation of enterocytes labelled with tritiated thymidine is similar in the jejunum of axenic and holoxenic rats. On the contrary, the slower renewal in the ileum of axenic rats is due to the smaller number of cells which must be replaced as well as to lower cell production (Meslin, Sacquet and Raibaud, 1974 ; Meslin, Sacquet and Riottot, 1981). Enterocyte age and degree of differentiation may at least partly explain the differences in microvillus length that we observed in the ileum.

3) Microvillus size and enzyme activities. - In the terminal part of the small intestine where the microflora is more abundant, enzyme activities are lower in holoxenic than in axenic rats. Alkaline phosphatase activity is decreased by 22,29 and $46 \%$ and the protein extracted from the sampled brush border by 5, 19 and $17 \%$, respectively, in the duodenum, jejunum and ileum of rat with a complete microflora (Reddy, 1971, 1972). Kawai and Morotomi (1978) also noted that specific alkaline phosphatase activity is 2.3 times lower in the foregut of holoxenic rats ; this is also true of the different enzyme activities in the small intestine of mice (Yolton and Savage, 1976 ; Whitt and Savage, 1980, 1981).

The variation in microvillus length reported in the present study is similar to that of brush border protein and the specific activity of alkaline phosphatase ; however, changes in microvillus length are not as marked and they do not prove any mathematical correlation between brush border development and enzyme activities in the microvilli. The enterocytes can also react to enzymes present in the gut lumen. Balas et al. (1980) reported a shortening of microvilli in the jejunum of holoxenic hamster after pancreatic duct ligation. Reddy, Pleasants and Wostmann (1969) found that germfree rats showed higher levels of amylase, trypsin and chymotrypsin in intestinal contents than conventional animals. One way in which the microflora might affect the length of microvilli would be by partially inactivating these enzymes in the gut lumen. Whatever the mechanism is, our results should be taken into consideration when comparing absorption in axenic and holoxenic animals, if that absorption is directly proportional to the apical surface of the enterocyte.

Recu en juillet 1982.

Accepté en janvier 1984

Acknowledgements. - We wish to thank Mrs. F. Desnoyers of the "Station de Recherches de Nutrition " for the use of material and the electron micrographs, Mr. J. P. Bouchet of the same research laboratory for statistical analysis of the results, and Ms. Alice Daifuku for editing the English manuscript. 
Résumé. Influence de la flore microbienne sur les dimensions des microvillosités de l'entérocyte chez le rat.

La longueur et le diamètre des microvillosités des entérocytes situés à mi-hauteur des villosités ont été mesurés sur les photographies de microscopie électronique. L'étude a porté sur le duodénum, le jéjunum et l'iléon de rats axéniques (germ-free) et de rats holoxéniques (conventionnels) consanguins, et dans les mêmes conditions de nutrition. Quel que soit le niveau intestinal étudié, les microvillosités sont significativement plus courtes en présence de la flore microbienne. La diminution de longueur des microvillosités, due à la présence de la flore microbienne, exprimée en pourcentage de celle des rats axéniques, est respectivement de $5 \%$ au duodénum, $9 \%$ au jéjunum et $18 \%$ à l'iléon. II n'en est pas de même pour le diamètre des microvillosités, seules les valeurs au niveau de l'iléon chez le rat axénique sont significativement les plus faibles; les autres valeurs ne diffèrent pas entre elles. En conclusion, la présence de la flore microbienne totale conduit à une diminution de la longueur des microvillosités des entérocytes. Ces résultats sont discutés par rapport aux études sur le renouvellement et l'activité enzymatique de l'épithélium intestinal.

\section{References}

ABRAMS G. D., BAUER H., SPRINZ H., 1963. Influence of the normal flora on mucosal morphology and cellular renewal in the ileum. A comparison of germ-free and conventional mice. $L a b$. Invest., 12, 355-364.

ALTMANN G. G., ENESCO M., 1967. Cell number as a measure of distribution and renewal of epithelial cells in the small intestine of growing and adult rats. Am. J. Anat., 121, 319-336.

ANDERSON J. H., TAYLOR B., 1973. Scanning and transmission electron microscopic studies of jejunal microvilli of the rat, hamster and dog. J. Morph., 141, 281-292.

BALAS D., SENEGAS-BALAS F., BERTRAND C., FREXINOS J., RIBET A., 1980 . Effects of pancreatic duct ligation on the hamster intestinal mucosa. Histological findings. Digestion, 20, 157-167.

GUSTAFSSON B. E., MAUNSBACH A. B., 1971. Ultrastructure of the enlarged caecum in germfree rats. $Z$. Zellforsch., 120, 555-578.

JERVIS H. R., BIGGERS D. C., 1964. Mucosal enzymes in the caecum of conventional and germfree mice. Anat. Rec., 148, 591-597.

KAWAI Y., MOROTOMI M., 1978. Intestinal enzyme activities in germfree, conventional and gnotobiotic rats associated with indigenous microorganisms. Infect. Immun., 19, 771-778.

KENWORTHY R., ALLEN W. D., 1966. Influence of diet and bacteria on small intestinal morphology, with special reference to early weaning and Escherichia coli. Studies with germfree and gnotobiotic pigs. J. comp. Path., 76, 291-296.

KEULS M., 1952. The use of studentized range in connection with an analysis of variance. Euphytica, 1, 112-122.

LEBLOND C. P., STEVENS C. E., 1948. The constant renewal of the intestinal epithelium in the albino rat. Anat. Rec., 100, 357-378.

LEESON T. S., LEESON C. R., 1981. Variation in height of microvilli in rat duodenal enterocytes. I.R.C.S. Medical Science, 9, 919-920.

MESLIN J. C., SACQUET E., GUENET J. L., 1973. Action de la flore bactérienne sur la morphologie et la surface de la muqueuse de l'intestin grêle du rat. Ann. Biol. anim. Bioch. Biophys., 13, 203-214.

MESLIN J. C., SACQUET E., RAIBAUD P., 1974. Action d'une flore microbienne qui ne déconjugue pas les sels biliaires sur la morphologie et le renouvellement cellulaire de la muqueuse de l'intestin grêle du rat. Ann. Biol. anim. Bioch. Biophys., 14, 709-720.

MESLIN J.-C., SACQUET E., RIOTTOT M., 1981. Effect of various modifications in the diet on ileal epithelium renewal in germ-free and conventional rats. Reprod. Nutr. Déve/op., 21, 651659.

MISCH D. W., GIEBEL P. E., FAUST R. G., 1980. Intestinal microvilli : responses to feeding and fasting. Eur. J. Cell. Biol., 21, 269-279. 
MOON H. W., 1971. Epithelial cell migration in the alimentary mucosa of the suckling pig. Proc. exp. Biol. Med., 137, 151-154.

NEWMAN D., 1939. The distribution of range in samples from a normal population expressed in terms of an independent estimate of standard deviation. Biometrika, 31, 20-30.

PALAY S. L., KARLIN L. J., 1959. An electron microscopic study of the intestinal villus. 1. The fasting animal. J. biophys. biochem. Cytol., 5, 363-371.

PHILLIPS A. D., FRANCE N. E., WALKER-SMITH J. A., 1979. The structure of the enterocyte in relation to its position on the villus in childbook : An electron microscopical study. Histopathology 3, 117-130.

REDDY B. S., 1971. Calcium and magnesium absorption: role of intestinal microflora. Fed. Proc., 30, 1815-1821.

REDDY B. S., 1972. Studies on the mechanism of calcium and magnesium absorption in germfree rats. Arch. Biochem. Biophys., 149, 15-21.

REDDY B. S., PLEASANTS J. R., WOSTMANN B. S., 1969. Pancreatic enzymes in germfree and conventional rats fed chemically defined, water-soluble diet free from natural substrates. J. Nutr., 97, 327-334.

STENDLING R., HELANDER H. F., 1981. Stereological studies on the small intestinal epithelium of the rat. 1. The absorptive cells of the normal duodenum and jejunum. Cell Tissue Res., 217, 11-21.

TONER P. G., CARR K. E., WYBURN G. M., 1971. Chapter 2. Intestine Mucosal architecture and cell turnover, 55-127. In TONER P. G., CARR K.E., WYBURN G. M., The digestive system, An ultrastructural atlas and review. Butterworths Publ.

WHITT D. D., SAVAGE D. C., 1980. Kinetics of changes induced by indigenous microbiota in the activity levels of alkaline phosphatase and disaccharidases in small intestinal enterocytes in mice: Infect. Immun., 29, 144-151.

WHITT D. D., SAVAGE D. C., 1981. Influence of indigenous microbiota on amount of protein and activities of alkaline phosphatase and dissacharidases in extracts of intestinal mucosa in mice. Appl. environ. Microbiol., 42, 513-520.

YOLTON D. P., SAVAGE D. C., 1976. Influence of certain indigenous gastro-intestinal microorganisms on duodenal alkaline phosphatase in mice. Appl. environ. Microbiol., 31, 880-888. 